\title{
Endotoxin and CD14 in the progression of biliary atresia
}

Ming-Huei Chou ${ }^{1,2}$, Jiin-Haur Chuang ${ }^{2,3}$, Hock-Liew Eng ${ }^{4}$, Ching-Mei Chen ${ }^{4}$, Chiou-Huey Wang ${ }^{5}$, Chao-Long Chen ${ }^{3}$, Tsun-Mei Lin ${ }^{1,5,6^{*}}$

\begin{abstract}
Background: Biliary atresia (BA) is a typical cholestatic neonatal disease, characterized by obliteration of intra- and/ or extra-hepatic bile ducts. However, the mechanisms contributing to the pathogenesis of BA remain uncertain. Because of decreased bile flow, infectious complications and damaging endotoxemia occur frequently in patients with BA. The aim of this study was to investigate endotoxin levels in patients with BA and the relation of these levels with the expression of the endotoxin receptor, CD14.
\end{abstract}

Methods: The plasma levels of endotoxin and soluble CD14 were measured with a pyrochrome Limulus amebocyte lysate assay and enzyme-linked immunosorbent assay in patients with early-stage BA when they received the Kasai procedure (KP), in patients who were jaundice-free post-KP and followed-up at the outpatient department, in patients with late-stage BA when they received liver transplantation, and in patients with choledochal cysts. The correlation of CD14 expression with endotoxin levels in rats following common bile duct ligation was investigated.

Results: The results demonstrated a significantly higher hepatic CD14 mRNA and soluble CD14 plasma levels in patients with early-stage BA relative to those with late-stage BA. However, plasma endotoxin levels were significantly higher in both the early and late stages of BA relative to controls. In rat model, the results demonstrated that both endotoxin and CD14 levels were significantly increased in liver tissues of rats following bile duct ligation.

Conclusions: The significant increase in plasma endotoxin and soluble CD14 levels during BA implies a possible involvement of endotoxin stimulated CD14 production by hepatocytes in the early stage of BA for removal of endotoxin; whereas, endotoxin signaling likely induced liver injury and impaired soluble CD14 synthesis in the late stages of BA.

\section{Background}

Biliary atresia (BA) is a typical cholestatic neonatal disease, characterized by obliteration of intra- and/or extra-hepatic bile ducts with repeated episodes of cholangitis and progressive liver fibrosis and cirrhosis [1-3]. However, the mechanisms contributing to the pathogenesis of BA remain uncertain. A decrease of bile flow to the bowel may promote bacterial translocation to the liver and increase endotoxin or lipopolysaccharide (LPS) levels in the peripheral circulation [4]. LPS represent the major component of the outer membrane of Gramnegative bacteria and has been implicated in sepsis,

\footnotetext{
* Correspondence: Itmei@mail.ncku.edu.tw

${ }^{1}$ Institute of Basic Medical Sciences, National Chang Kung University, Tainan, Taiwan

Full list of author information is available at the end of the article
}

organ failure, and shock [5]. In experimental studies on healthy animals, LPS is cleared from the circulation within a few minutes of intravenous injection, and the majority of LPS is traced to the liver [6,7]. In addition to clearing LPS, the liver also responds to the presence of LPS with production of cytokines and reactive oxygen intermediates. Accumulating evidence suggests that both endotoxins and pro-inflammatory cytokines participate in liver damage during endotoxemia $[8,9]$.

CD14 is a glycosylphosphatidylinositol-anchored LPS receptor. It was first reported as a differentiation marker expressed on the surface of macrophages, neutrophils, and other myeloid lineage cells [10-13]. Human hepatocytes demonstrate production of CD14 similar to that of an acute phase protein [14]. However, there is limited information on the proportional change of CD14 in the

\section{Biomed Central}


liver and the consequent pathogenetic effects on LPSinduced liver injury. Although increased expression of CD14 in surgically biopsied specimens of BA have been reported, the exact mechanism of such over-expression of CD14 is yet to be elucidated [15]. Our previous investigation revealed that the single nucleotide polymorphism at CD14/-159 is associated with the development $\mathrm{BA}$ and idiopathic neonatal cholestasis [16]. How the liver responds to LPS-induced injury is virtually unknown at present $[17,18]$. Kupffer cells and sinusoidal endothelial cells express the membrane form of CD14 (mCD14) in the liver $[19,20]$, while hepatocytes are the main producers of soluble CD14 (sCD14) $[21,22]$. However, the proportional change of CD14 production in the liver and the subsequent effects on LPS-induced liver injury during BA is not clear.

In this study, we investigated the role of CD14 in BAassociated liver injury, with particular emphasis on the correlation between CD14 expression and endotoxin levels in the liver tissue and plasma of patients in the early and late stages of BA. We further elucidated the expression and regulation of CD14 in a rat model following bile duct ligation (BDL).

\section{Methods}

\section{Patients and samples}

Liver biopsy specimens were obtained from nine patients with early-stage BA (four males and five females) during Kasai's procedure (KP), from nine patients with late-stage BA (four males and five females) during liver transplantation for failed KP, and from nine patients with choledochal cysts (CCs) during surgical correction (2 male and 7 female). Control liver biopsy samples were obtained from five children with neonatal hepatitis and two who had focal hepatoblastoma. Plasma samples were obtained from 41 patients with early-stage BA, 25 patients post-KP who were jaundice-free and were followed-up at the outpatient department (OPD), 49 patients with late-stage BA, 9 patients with $\mathrm{CC}$, and 7 healthy young infants. All of the liver and blood samples were immediately frozen at $-80^{\circ} \mathrm{C}$ for later laboratory tests. The clinical characteristics and detailed history of the patients, including the age when the patient underwent the procedure, sex, serum aspartate aminotransferase (AST) levels, and total bilirubin are summarized in Table 1. Informed consent was obtained from the patients or their legal guardians, and the experiments were approved by the Ethics \& Clinical Trial Committee of the Chang Gung Memorial Hospital, Taiwan.

\section{Animals}

Male Sprague-Dawley rats weighting 300-330 g and about 8 weeks old were divided into three groups: the BDL group $(n=48)$ received a common bile duct complete double ligation, the sham group received a sham operation ( $\mathrm{n}=48)$, and the normal control group $(\mathrm{n}=6)$. All animal experiments were performed in accordance with and approved by the Animal Care and Use Committee of Chang Gung Memorial Hospital at Kaohsiung. Blood samples were collected at time of sacrifice ( $3 \mathrm{hrs}, 6$ hrs, 12 hrs, 24 hrs, 3 days, 7 days, 14 days, and 21 days), and six rats were included in each subgroup. Serum enzymes and bilirubin levels were determined using a biochemistry auto-analyzer (Model 7450; Hitachi, Tokyo, Japan). Liver tissues were either snap frozen and homogenized in T-PER tissue protein extraction reagent (Pierce Chemical, Rockford, IL) for protein determination or fixed in $4 \%$ paraformaldehyde and embedded in paraffin for immunohistochemical analysis.

\section{Determination of $\mathrm{sCD} 14$ levels by ELISA}

The sCD14 levels of plasma were determined using a commercially available enzyme-linked immunosorbent assay (ELISA; R \& D Systems, Minneapolis, MN) according to the manufacture's instructions. Samples were diluted 1:200 and analyzed, and each sample was measured in duplicate.

\section{Limulus amebocyte lysate (LAL) test}

Plasma specimens were collected aseptically in nonpyrogenic containers. The plasma and liver specimens were diluted 1:10 and assayed for endotoxin with a commercially available pyrochrome LAL kit (Associates of Cape Cod, Falmouth, MA) according to the manufacture's instructions.

\section{Real-time quantitative reverse transcription-polymerase chain reaction ( $q R T-P C R$ )}

Frozen liver samples $(0.1 \mathrm{~g} /$ per sample) were homogenized, and total RNA was extracted using TRIzol (Invitrogen, Carlsbad, CA). The RNA isolates were quantified at $\mathrm{A}_{260 / 280}$ ratio of 1.7-2.0. A total of $2 \mu \mathrm{g}$ of RNA was added to $0.1 \mu \mathrm{g}$ of oligo-d $(\mathrm{T})_{15}$ following the protocol for SuperScripIIRT (Invitrogen, Carlsbad, CA). Quantitative PCR was performed in a final volume of 20- $\mu$ l SYBR Green PCR mixture (Applied Biosystems, Foster City, CA), and each sample was analyzed in duplicate. Each reaction mixture contained 0.2 pmole/ul of each primer, $1 \times$ SYBR Green PCR Master Mix, and 1-5 ng of cDNA. Thermal cycling was initiated with a 2 min incubation at $50^{\circ} \mathrm{C}$, followed by a denaturation step of $10 \mathrm{~min}$ at $95^{\circ} \mathrm{C}$, and then 40 cycles of PCR consisting of $95^{\circ} \mathrm{C}$ for 15 seconds, $60^{\circ} \mathrm{C}$ for 20 seconds, and $72^{\circ} \mathrm{C}$ for 30 seconds. $\beta$-actin was used as an internal control for analyzing CD14 mRNA levels. The sequence of the PCR primers were designed based on CDNA sequences from Genbank as follows: CD14 forward primer 5'-TAT GCT GACACG GTC AAG GC-3', CD14 reverse primer 5'-ATT GTC AGA CAG GTC TAG GC-3', $\beta$-actin 
Table 1 Clinical characteristics of the child patients for this study

\begin{tabular}{|c|c|c|c|c|c|c|c|}
\hline & Con-C & Early $\mathrm{s}$ & of $B A$ & OPD & Late $s$ & of $B A$ & $\mathrm{CC}$ \\
\hline & Plasma & Plasma & Liver & Plasma & Plasma & Liver & Plasma \& Liver \\
\hline Sample No & 7 & 41 & 9 & 25 & 49 & 9 & 9 \\
\hline Age (months) & $18 \pm 24$ & $2.4 \pm 1.2$ & $2 \pm 1$ & $24 \pm 16$ & $15 \pm 10$ & $15 \pm 6$ & $22 \pm 14$ \\
\hline $\operatorname{Sex}(M / F)$ & $4 / 3$ & $23 / 16$ & $4 / 5$ & $7 / 18$ & $19 / 21$ & $4 / 5$ & $2 / 7$ \\
\hline AST (U/I) & ND & $200 \pm 175^{\dagger}$ & $181 \pm 130$ & ND & $276 \pm 241$ & $246 \pm 114$ & $298 \pm 228$ \\
\hline T. Bil (mg/dl) & ND & $9.0 \pm 2.9^{\dagger}$ & $9.4 \pm 3.0$ & ND & $16 \pm 1.0$ & $18 \pm 10$ & $6.5 \pm 6.0^{\dagger}$ \\
\hline D. Bil (mg/dl) & ND & $6.3 \pm 2.0^{\dagger}$ & $7.0 \pm 2.3^{\dagger}$ & ND & $12 \pm 7.5$ & $13 \pm 7.2$ & $5.6 \pm 4.0^{\dagger}$ \\
\hline $\mathrm{sCD} 14(\mu \mathrm{g} / \mathrm{ml})$ & $4.0 \pm 0.8$ & $4.7 \pm 1.7^{\dagger}$ & $47 \pm 14$ & $4.2 \pm 1.4^{\dagger}$ & $2.7 \pm 1.5^{* \neq}$ & $49 \pm 12$ & $4.0 \pm 2.0^{\dagger}$ \\
\hline Endotoxin (EU/ml) & $2.0 \pm 1.0$ & $6.2 \pm 5.0^{* \neq}$ & $17 \pm 4.0$ & $2.2 \pm 5.0^{\dagger}$ & $6.7 \pm 5.0^{* \neq}$ & $16 \pm 7.0$ & $6.5 \pm 4.0^{* \neq}$ \\
\hline
\end{tabular}

Con-C, control-children; Early stage of BA, Kasai's procedure for biliary atresia; OPD, Jaundice-free post-Kasai BA patients followed at the outpatient department; Late stage of BA, liver transplantation for biliary atresia; CC, choledochal cyst; AST, alanine aminotransferase; D. Bil, direct bilirubin; T. Bil, total bilirubin; ND, non detection; sCD14, souble CD14; y, years. Value are expressed as the mean \pm SD. ${ }^{*} P<0.05$ vs control; ${ }^{\dagger} P<0.05$ vs late stage of $\mathrm{BA} ;{ }^{\ddagger} P<0.05$ vs $\mathrm{OPD}$.

forward primer 5'-TCA CCC ACA ATG TGC CCA TCT TCG A-3', and $\beta$-actin reverse primer 5'-CAG CGG AAC CGC TCA TTG CCA ATG G-3'.

The quantification of the CD14 mRNA was achieved with an ABI PRISM 7700 Sequence Detection System (Applied Biosystems, Warrington, WA) using comparative methods. $\mathrm{Ct}$ values of CD14 were normalized to the $\mathrm{Ct}$ value of a housekeeping gene ( $\beta$-actin).

\section{Immunohistochemical staining for CD14 and lipid A}

Immunoreactive CD14 and lipid-A staining was performed on paraffin-embedded, formalin fixed, archival human liver tissues obtained from the Department of Pathology, Kaohsiung Chang Gung Memorial Hospital, Taiwan. In the animal study, formalin-fixed, paraffinembedded liver tissues were used. Two-micrometer sections were deparaffinized, treated with $3 \%$ hydrogen peroxide to inactivate the endogenous peroxidase activity, and microwaved for $7 \mathrm{~min}$ in $10-\mathrm{mM}$ citrate buffer ( $\mathrm{pH}$ 6.0) to retrieve the antigen. The sections were then incubated in PBS supplemented with 5\% fetal calf serum for $10 \mathrm{~min}$ to block background interactions. The sections were then incubated with a rabbit anti-CD14 antibody (Santa Cruz Biotechnology, Santa Cruz, CA) or a mouse anti-lipid A antibody (HyCult Biotechnology, The Netherlands) at $37^{\circ} \mathrm{C}$ for $2 \mathrm{hrs}$. The sections were washed with PBS supplemented with $0.05 \%$ Tween 20 and then incubated for $10 \mathrm{~min}$ with the secondary antibodies (SuperPicture; Zymed Laboratories, Francisco, CA). DAB color substrate (DAKO, Carpinteria, CA) was added to cover each section, and the reaction was stopped with $\mathrm{dd}_{2} \mathrm{O}$. The slides were counterstained with hematoxylin, and mounted in mounting medium.

\section{In situ hybridization}

In situ hybridization was performed essentially as described by Wilkinson[23]. The riboprobe was generated from a pGEM-T vector containing a 250 bp cDNA sequence of CD14 and labeled with DIG-11-UTP by in vitro transcription with SP6 and T7 RNA polymerase, followed by DIG RNA labeling (Roche Applied Science, Germany). Liver tissues were treated according to the protocol for immunohistochemical analysis with deparaffinization, rehydration, removal of endogenous peroxidase activity, and antigen retrieval. Sections were digested with $20 \mu \mathrm{g} / \mathrm{ml}$ of proteinase $\mathrm{K}$ solution at $37^{\circ} \mathrm{C}$ for $25 \mathrm{~min}$ and then prehybridized with $5 \times$ SSC buffer. A total of $50-\mu \mathrm{l}$ hybridization mixture containing denatured RNA probes was used and hybridized with the sections at $55^{\circ} \mathrm{C}$ overnight. After hybridization, the sections were treated with $20 \mu \mathrm{g} / \mathrm{ml}$ of RNase solution at $37^{\circ} \mathrm{C}$ for $30 \mathrm{~min}$ to remove free RNA probes and then washed with $1 \times$ SSC buffer for $5 \mathrm{~min}$ and $0.2 \times \mathrm{SSC}$ containing $0.01 \% \mathrm{SDS}$ in a $55^{\circ} \mathrm{C}$ water bath for $15 \mathrm{~min}$. Sections were blocked in PBS supplemented with 5\% FBS and incubated with an antidigoxigenin antibody conjugated with horseradish peroxidase (diluted 1:1000, containing 2\% FCS) in blocking buffer for $2 \mathrm{~h}$ at room temperature. The sections were washed with PBS supplemented with $0.05 \%$ Tween 20 and then DAB color substrate (DAKO, Carpinteria, CA) was added to cover each section, and the reaction was stopped with $d d \mathrm{H}_{2} \mathrm{O}$. The slides were counterstained with hematoxylin, and mounted in mounting medium.

\section{Statistics analysis}

Data are presented as the mean \pm standard deviation (SD). The distributions of paired measurements were compared using the nonparametric Wilcoxon matchedpairs test. The Mann-Whitney test and Wilcoxon signed-ranks test (nonparametric) were used to evaluate the statistical significance of the results using the SPSS16 software package (SPSS, Chicago, USA). A $P$ value of less than 0.05 was considered significant.

\section{Results}

Plasma CD14 and endotoxin levels in patients with BA

Plasma sCD14 levels were analyzed by ELISA and found to be significantly higher in patients with early-stage BA 
(4696 $\pm 1652 \mathrm{ng} / \mathrm{ml})$, patients with BA who were jaundicefree and followed up at the OPD $(4308 \pm 1428 \mathrm{ng} / \mathrm{ml})$, and patients with CCs $(4393 \pm 1900 \mathrm{ng} / \mathrm{ml})$ relative to patients with late-stage BA $(2722 \pm 1453 \mathrm{ng} / \mathrm{ml}$, $P<0.001)$. Although sCD14 levels in the early-stage BA, OPD, and CC groups were higher than controls (3879 \pm $767 \mathrm{ng} / \mathrm{ml}$ ), these differences were not statistically significant $(P=0.134, P=0.447$, and $P=0.442$, respectively) (Figure 1). There were seven patients with BA whose plasma samples were available for both the early and late stages. For these patients, plasma sCD14 levels were significantly higher in the early stage $(4445 \pm 237 \mathrm{ng} / \mathrm{ml})$ compared to those in the late stage $(2183 \pm 153 \mathrm{ng} / \mathrm{ml})$ based on paired $\mathrm{t}$-test analysis $(P<0.001)$.

There was no significant difference in endotoxin levels between the patients with early-stage BA $(6.18 \pm 4.59$ $\mathrm{EU} / \mathrm{ml})$ and those with late-stage BA $(6.6 \pm 4.58 \mathrm{EU} / \mathrm{ml}$, $P=0.74$ ) However, the levels of plasma endotoxin in patients in either stage of BA and in patients with $\mathrm{CC}$ $(6.51 \pm 4.27 \mathrm{EU} / \mathrm{ml})$ were significantly higher than controls $(2.2 \pm 1.1 \mathrm{EU} / \mathrm{ml}, P<0.001)$. The plasma endotoxin levels in the patients with BA that were jaundicefree and followed up in the OPD $(2.8 \pm 1 \mathrm{EU} / \mathrm{ml})$ were markedly lower than those patients in either stage of BA and those with $C C(P<0.001)$ (Figure 2).

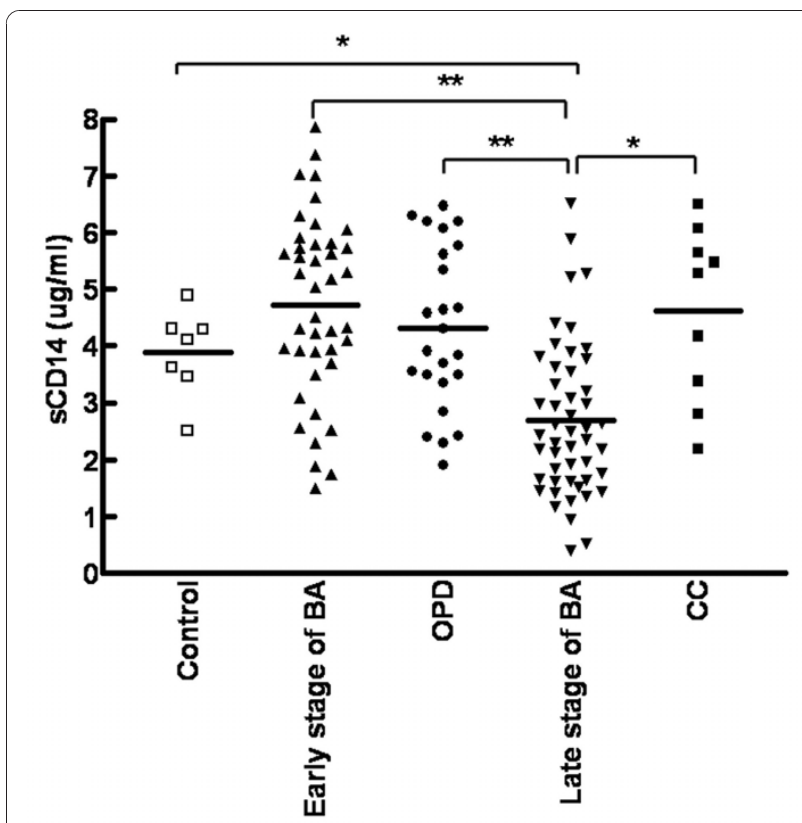

Figure 1 Plasma sCD14 levels in patients with BA. Quantitative analysis of soluble CD14 by ELISA in the plasma of 41 patients with early-stage biliary atresia (BA), 25 patients followed-up at the outpatient department (OPD) post-Kasai, 49 patients with late-stage BA, 9 patients with choledochal cysts (CC), and 7 healthy controls. Data represent the mean \pm SD from duplicate experiments. Statistical differences were tested by nonparametric Wilcoxon matched-pairs test. ${ }^{*} p<0.05$ and ${ }^{* *} p<0.01$ vs. late-stage BA.

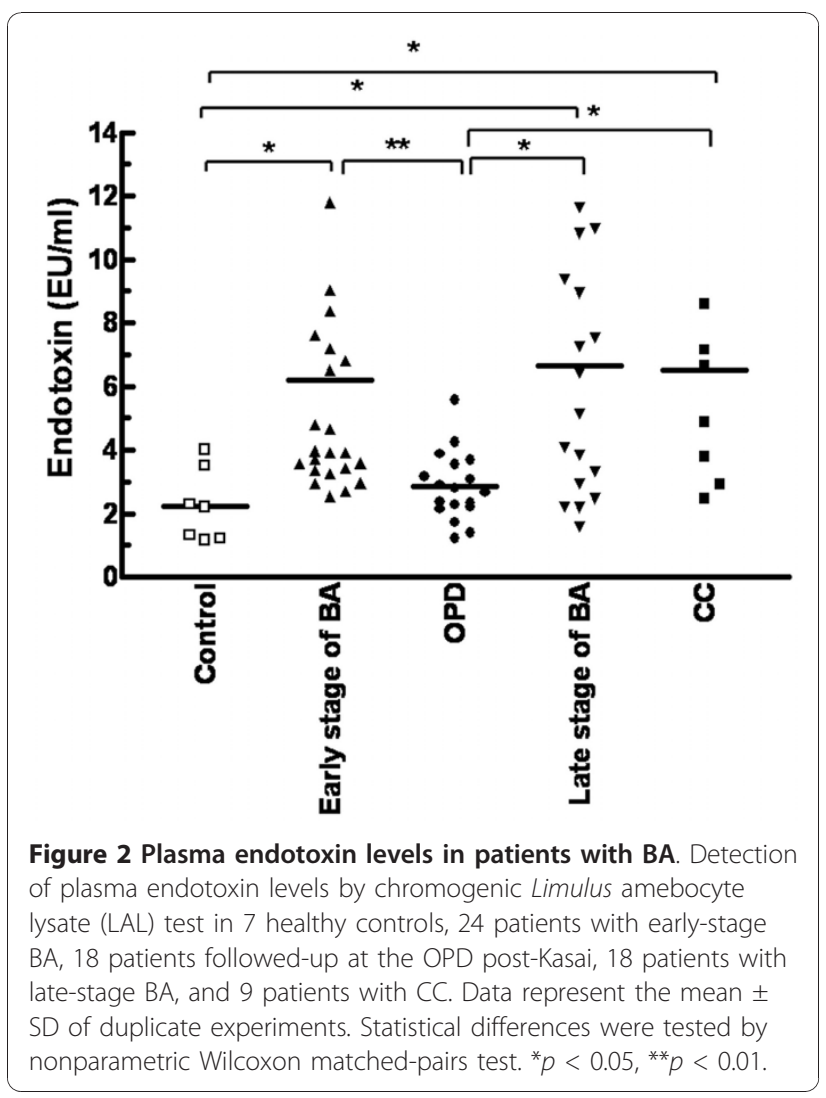

\section{CD14 mRNA and protein expression in liver tissues of patients with $B A$}

Paraffin-embedded liver sections from two control patients, five patients with early-stage BA, and five patients with late-stage BA were analyzed for CD14 localization by immunohistochemical staining. In all tissues, CD14 was observed in the parenchyma of the hepatic lobules, where Kupffer cells and sinusoidal endothelial cells were immunostained positive and the arterial and venous endothelium, bile duct epithelial cells, and hepatocytes were negative. However, in CC (Figure 3B) and early-stage BA tissues (Figure 3C), a clear and more intense CD14 staining was observed in Kupffer cells and sinusoidal endothelial cells. The intensity of CD14 expression was significantly higher in the early-stage BA tissues (Figure $3 \mathrm{C}$ ) compared to the latestage BA and control tissues (Figure 3D and 3A). To further ensure proper identification of the cell types expressing CD14 in the liver tissues, in situ hybridization of the CD14 mRNA was performed with a DIGlabeled CD14 sense (Figure 4A-C) and antisense RNA probe (Figure 4D-F). In addition to Kupffer cells and sinusoidal endothelial cells, hepatocytes and bile duct cells were also demonstrated positive for CD14 mRNA in the parenchyma of the hepatic lobules in control tissues (Figure 4A and 4D). However, in the early-stage 


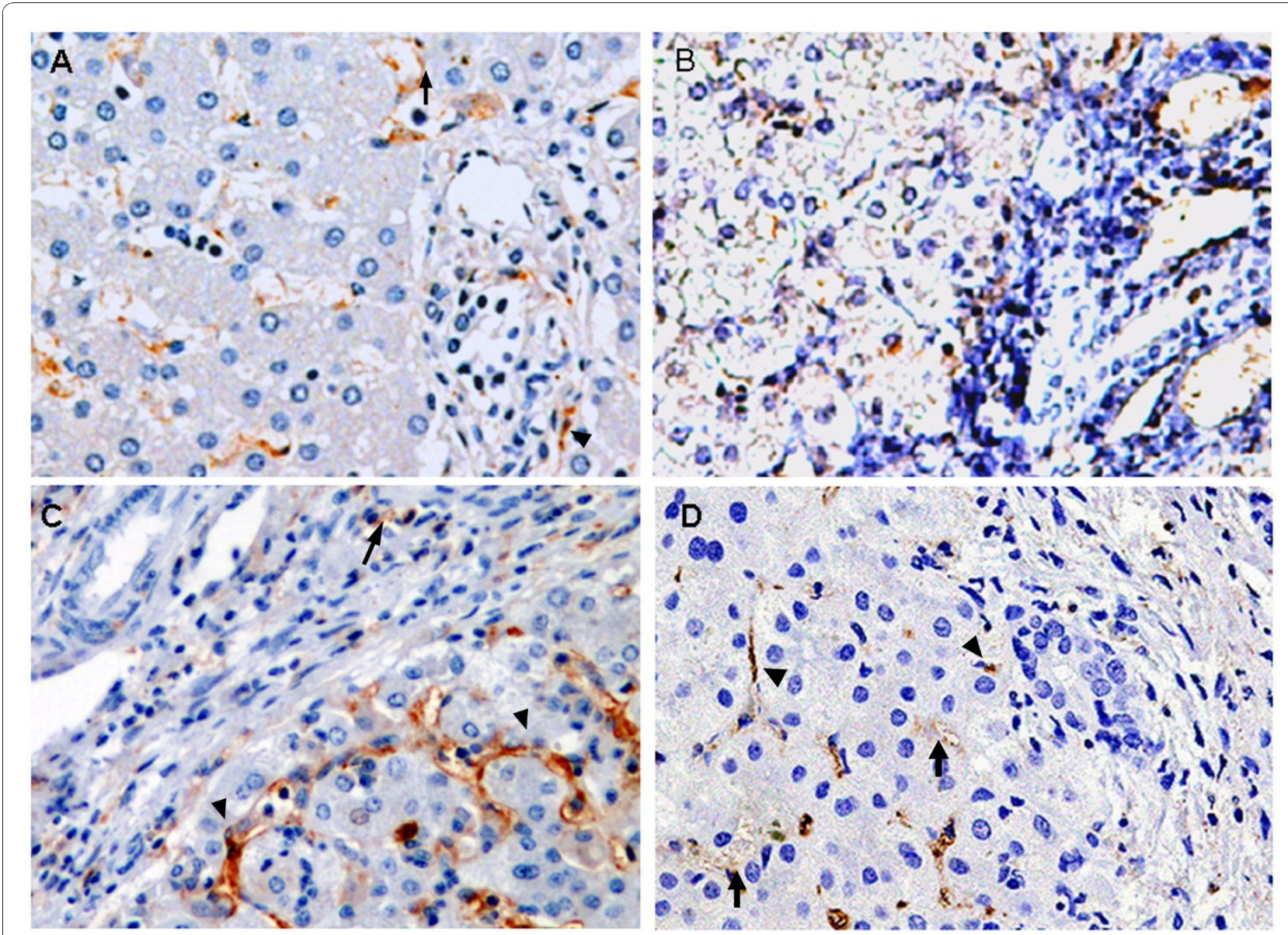

Figure 3 CD14 expression in liver tissues of patients with BA. Comparison of CD14 expression in paraffin-embedded liver tissue sections among the control group (biopsy from neonatal hepatitis and hepatoblastoma) (A), patients with CC (B), patients with early-stage BA (C), and patients with late-stage BA (D). Liver sections were stained with a monoclonal antibody against CD14 (dark brown) and counterstained with hematoxylin. Kupffer cells (arrow) and sinusoidal endothelial cells (arrowhead) showed positive immunostain for CD14. Original magnification: $\times 200$.

BA tissues (Figure 4B and 4E), the CD14 mRNA presented a constitutive and uniform expression pattern mainly localized in the hepatocytes and the bile duct epithelial cells (Figure 4E). The expression of the CD14 mRNA was higher in the early-stage BA tissues (Figure 4E) than that of control tissues (Figure 4D), but its expression was significantly decreased in the late-stage BA tissues due to loss of hepatocytes (Figure 4F). In addition, on qRT-PCR analysis, CD14 mRNA levels were 5 -fold higher in early-stage BA tissues $(n=9)$ relative to the late-stage BA tissues $(\mathrm{n}=9)(6.7 \pm 1.2 v s .1 .4 \pm$ $0.6, P=0.002)$.

The localization of endotoxin in the liver tissues Immunohistochemical staining using a monoclonal antibody against lipid A was performed in liver tissue sections for detecting the localization of endotoxin. In the normal liver tissues (Figure 5A), immunoreactivity to lipid A was weak or absent. However, lipid-A immunoreactivity was strongly detected around the portal area in hepatocytes, Kupffer cells, biliary epithelial cells, and some infiltrating cells in patients with $\mathrm{CC}$ (Figure $5 \mathrm{~B}$ ) and in patients with early-stage BA (Figure 5C). In patients with late-stage BA, immunoreactivity to lipid A was detected around sites of fibrous septum formation in hepatic parenchymal cells, Kupffer cells, and biliary epithelial cells (Figure 5D). In the liver of patients with BA, both hepatocytes and nonparenchymal liver cells, such as biliary epithelial cells and Kupffer cells, demonstrated evident uptake of endotoxin, paralleling the high circulating plasma levels of endotoxin.

\section{Serum enzymes and bilirubin levels in BDL rat model}

In the BDL rat model, hepatic injury was associated with an increase in serum alanine aminotransferase (ALT) and bilirubin levels. As shown in Figure 6, ALT increased to $1053 \mathrm{IU} / \mathrm{L}$ (BDL vs. sham; $P=0.001$ ) at Day 1 after ligation, indicating severe liver injury after BDL. ALT levels decreased afterward and reached a new 


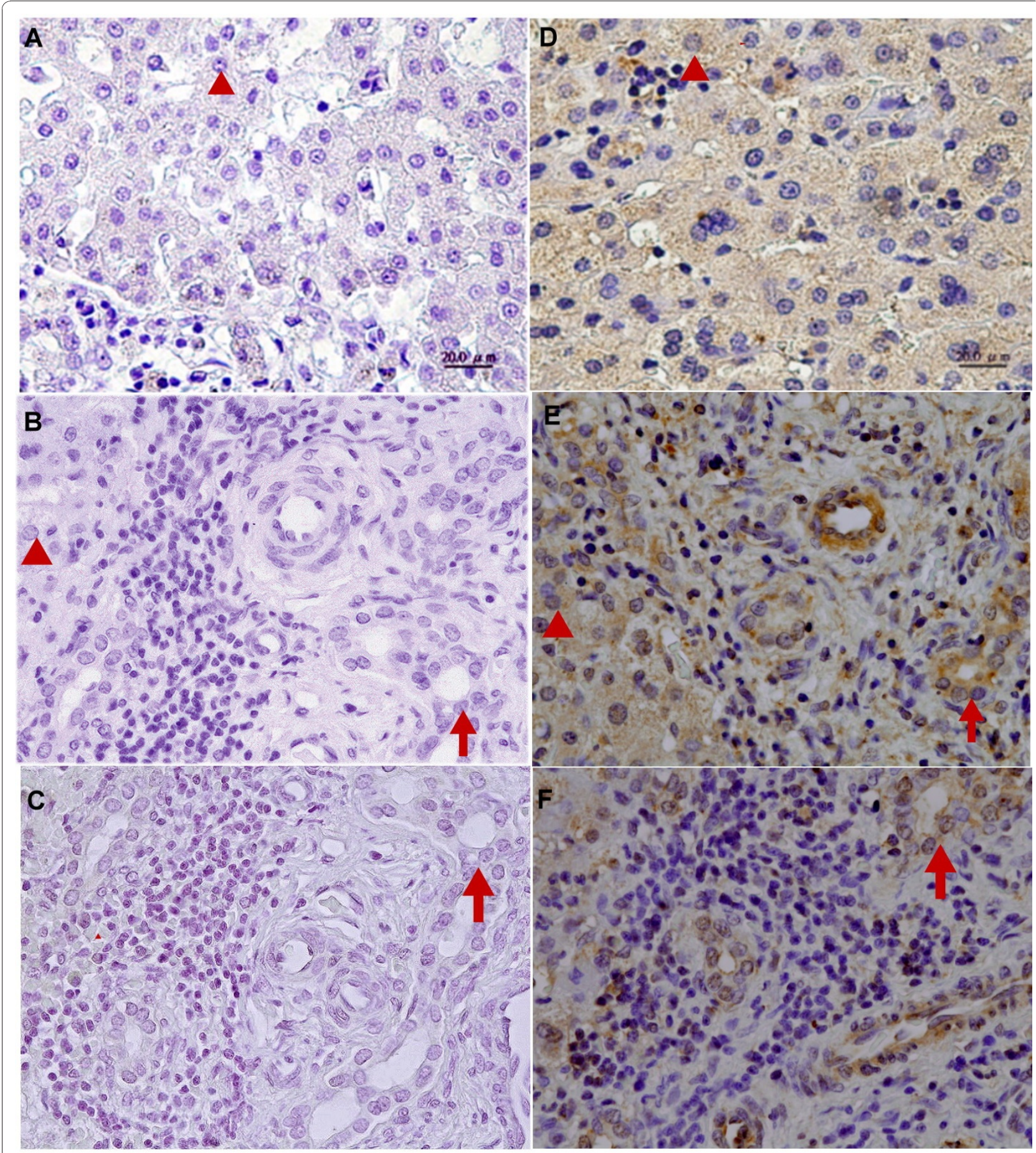

Figure 4 CD14 mRNA expression in liver tissues of patients with BA. In situ hybridization of CD14 mRNA in the livers of patients with earlyand late-stage BA. CD14 is stained brown by in situ hybridization with a DIG-labeled CD14 sense (A-C) and antisense RNA probe (D-F). The paraffin-embedded sections from patients with hepatoblastoma as control $(A, D)$, early-stage $B A(B, E)$ and late-stage BA (C, F) Tissues were counterstained with hematoxylin. The CD14 mRNA expression pattern mainly localized in the hepatocytes (arrowhead) and the bile duct epithelial cells (arrow). Original magnification: $\times 200$. 

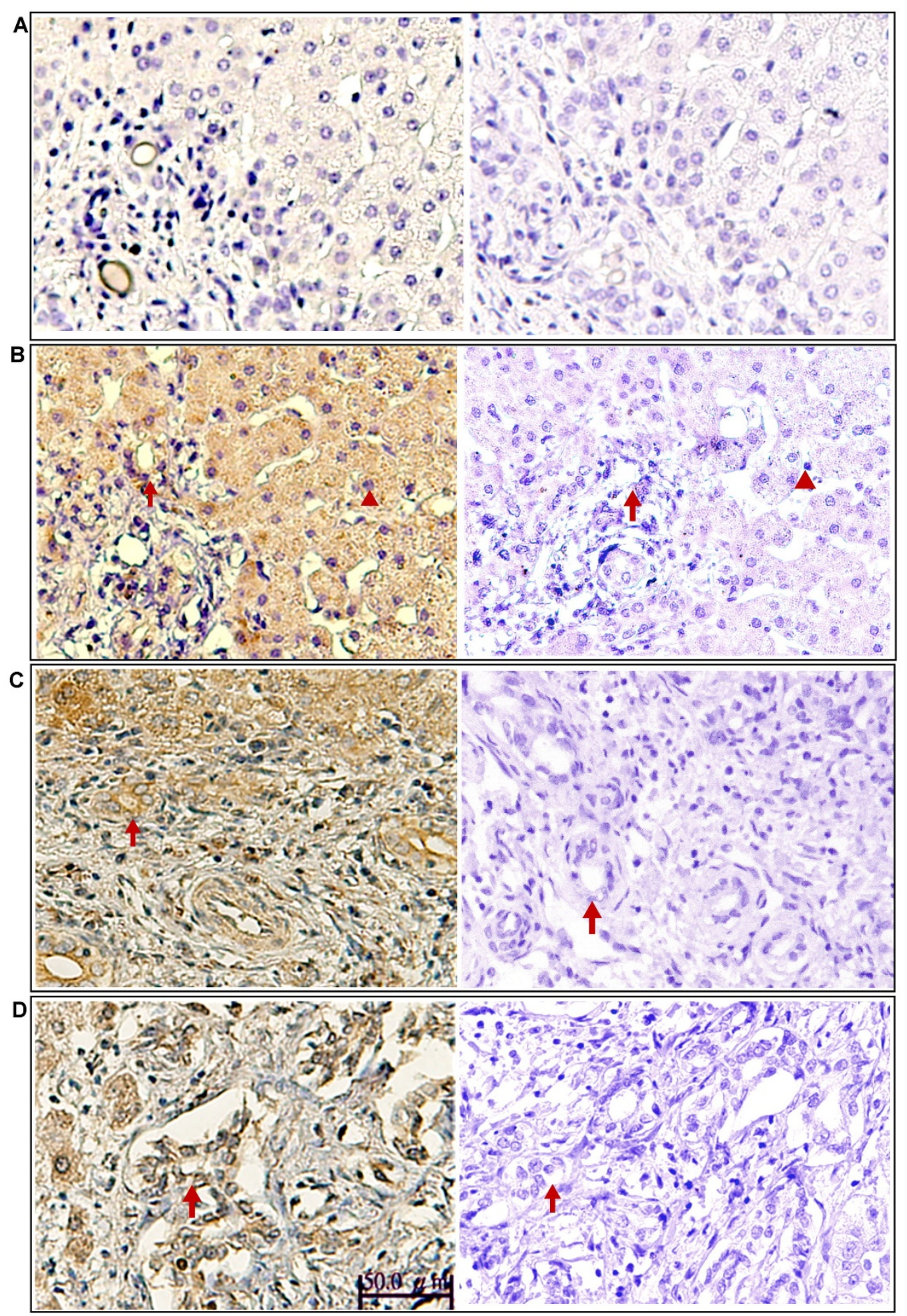

Figure 5 Endotoxin levels in liver tissues of patients with BA. Immunohistochemical staining for endotoxin in the liver tissues of controls (biopsy from neonatal hepatitis and hepatoplastoma) (A), patients with CC (B), patients with early-stage BA (C), and patients with late-stage BA (D). Liver sections were stained using a monoclonal antibody against lipid A (HM2046) (left column), mouse lgG1 isotype control antibody (ab27479) (right column) and counterstained with hematoxylin. Lipid-A immunoreactivity was detected in hepatocytes (arrowhead) and biliary epithelial cells (arrow), Original magnification: $\times 200$. 


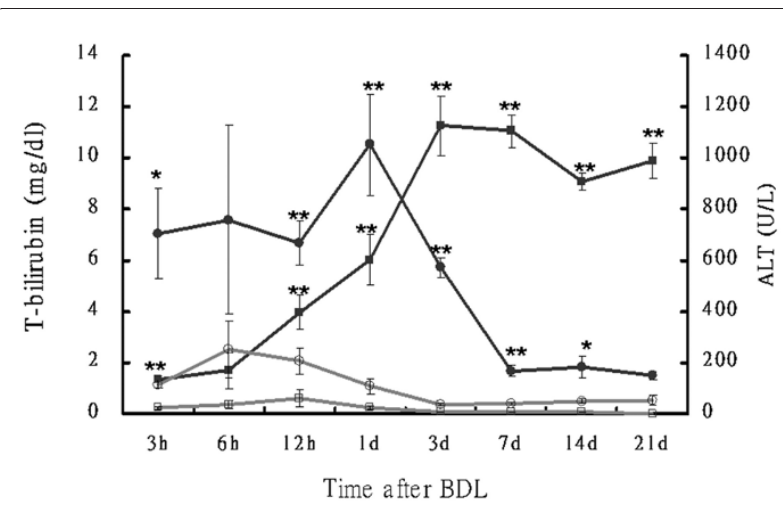

Figure 6 Total bilirubin and ALT levels in rats. Time course of total bilirubin (T-bilirubin; square) and alanine transaminase (ALT; circle) in rat plasma after bile duct ligation (BDL; closed symbols) or sham (open symbols) operation. Blood samples were collected at the time points indicated. T-bilirubin and ALT were assayed using a biochemistry auto-analyzer (Model 7450; Hitachi, Tokyo, Japan). Values are mean \pm SD $\left(n=6\right.$ in each subgroup). ${ }^{*} p<0.05$, ${ }^{* *} p<$ 0.005 (sham vs. BDL groups).

steady-state level of about $180 \mathrm{U} / \mathrm{L}$ after Day 7 postligation. However, the total bilirubin continuously increased after ligation and reached its peak at Day 3 (BDL vs. sham; $11.26 \pm 1.18$ vs. $0.1 \pm 0 \mathrm{mg} / \mathrm{dL}, P<0.001$ ) and remained high level throughout the BDL period. The endotoxin levels in the plasma and liver tissues were also significantly increased after Day 1 post-ligation and paralleled an increase in plasma bilirubin levels (Figure 7).

\section{CD14 and lipid-A detection in the BLD rat model}

Temporal expression of CD14 in hepatocytes was assessed via immunohistochemical analysis in rats.

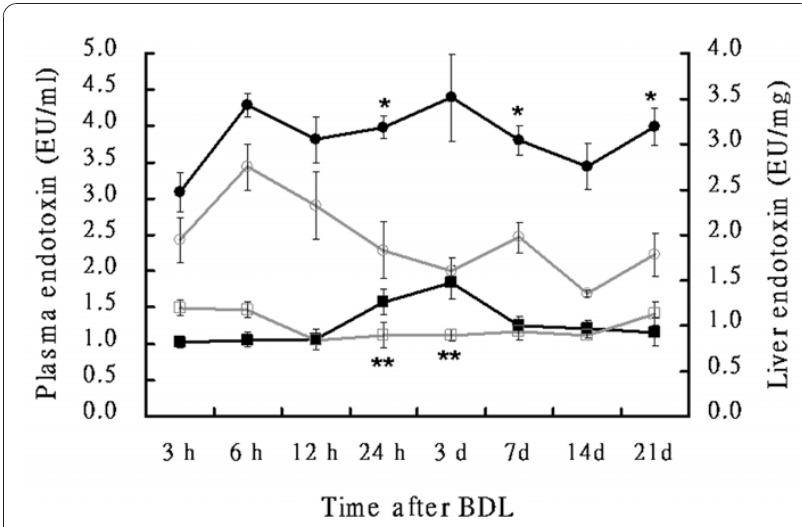

Figure 7 Endotoxin levels of plasma and liver tissues in rats Time course of endotoxin levels in the liver (circles) and plasma (squares) after BDL (closed symbols) or sham (open symbols) operation. Blood samples were collected at the time points indicated. Endotoxin was assayed using a pyrochrome LAL kit (Associates of Cape Cod, Falmouth, MA). Values are mean \pm SD ( $n=6$ in each subgroup). ${ }^{*} p<0.05,{ }^{* *} p<0.005$ (sham vs. BDL groups).
CD14 was expressed in the Kupffer cells, sinusoid endothelial cells and more strongly in hepatocytes around the portal zones (Figure 8B-F) in rat liver tissues. A significantly higher CD14 expression was discerned in hepatocytes of BDL rats (Figure 8C-F) as compared to the sham-operated group. Quantitative evaluation of CD14 positive cells in live tissues was performed by an experienced hepatopathologist. If CD14 positive cells were present in over $10 \%$ of the tissue area, CD14 was considered activated. As shown in Table 2, CD14 activation was a dynamic phenomenon in BDL group. The expression of CD14 in hepatocytes was enhanced at 3-6 h post-ligation and returned to baseline levels by $24 \mathrm{~h}$. Then, CD14 expression was demonstrated to increase again after 7 days. The BDL rats also shown a significantly higher CD14 activation in hepatocytes compared to the sham-operated group (Figure 8G). In situ hybridization of mRNA of CD14 was performed in rat liver tissues. In addition to Kupffer cells and sinusoidal endothelial cells, CD14 mRNA was demonstrated in hepatocytes and bile duct cells of the hepatic lobules in control tissues (Figure 9A and 9B). The expression of CD14 mRNA in liver tissue of BDL rats was higher than that of the sham-operated group at day 14 after BDL, especially in the hepatocytes (Figure 9D and 9C).

Hepatic endotoxin levels were higher in the BDL rats (Figure 10D-F) compared with the sham-operated group (Figure 10A-C) by immunohistochemical staining. Significantly higher endotoxin accumulation was observed in hepatocytes following BDL. Based on the extent and intensity of anti-lipid A stain, a semiquantitative method was used to calculate the ratio with the positive area over $10 \%$ in liver sections. As shown in Table 2 and Figure 10G, endotoxin was detected in liver tissues at 3 $\mathrm{h}$ in BDL and sham-operated rats. Like CD14 activation in the BDL group, endotoxin accumulation was returned to baseline levels by $24 \mathrm{~h}$ and then increased again after 7 days post ligation.

\section{Discussion}

Our results demonstrated for the first time the expression profile of sCD14 in patients with BA and found significantly higher CD14 mRNA and protein levels in early-stage BA relative to late-stage BA and CC. However, hepatic endotoxin levels remained very high, despite a significant increase in plasma endotoxin levels in patients with BA compared with control patients. The liver is thought to be involved in the systemic clearance and detoxication of endotoxin, and Kupffer cells and hepatocytes both contribute to clearing endotoxin via different recognition systems $[24,25]$. The production of $\mathrm{sCD} 14$ and LPS binding protein by hepatocytes could provide a powerful mechanism by which the liver carries 

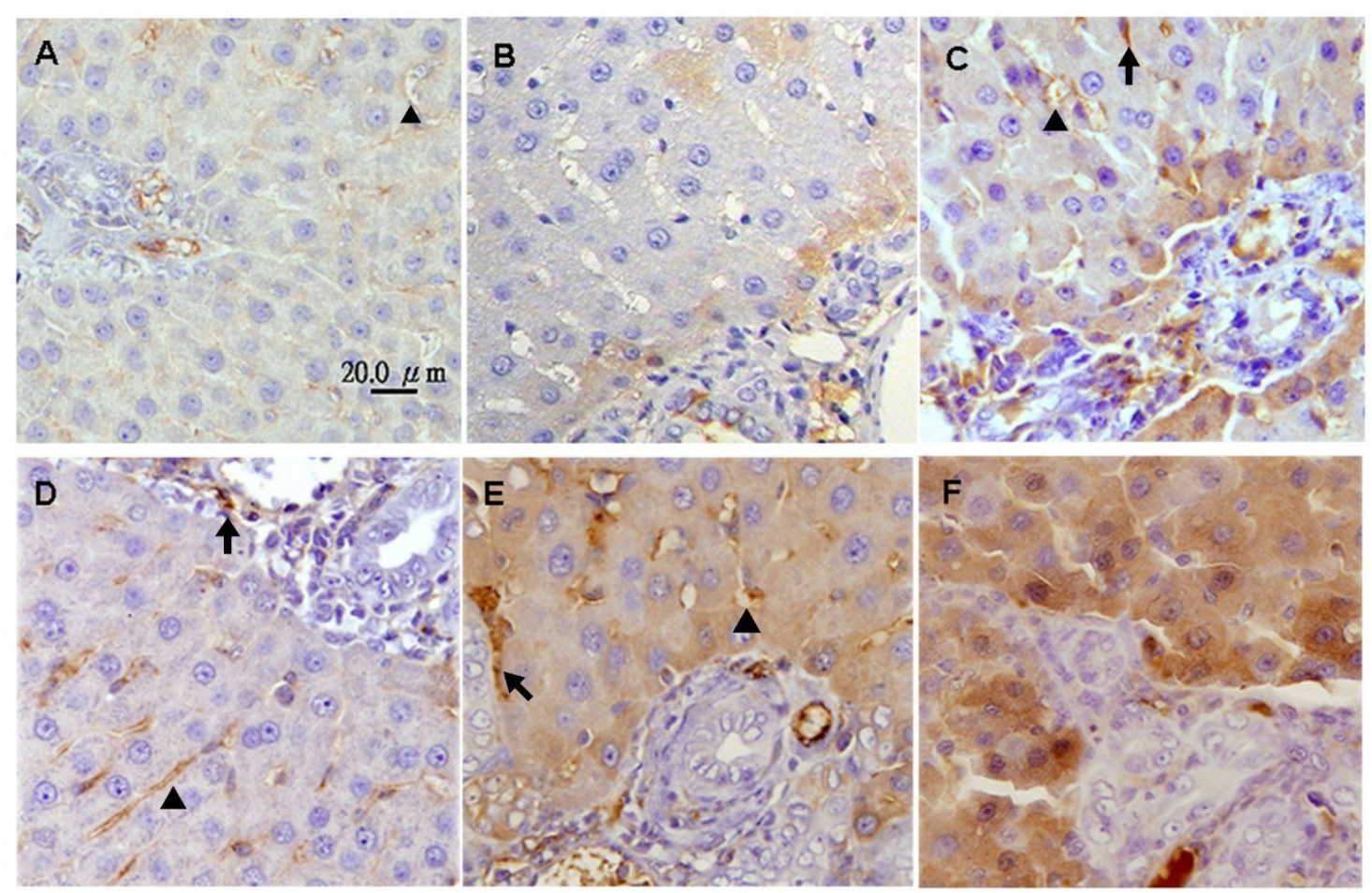

G

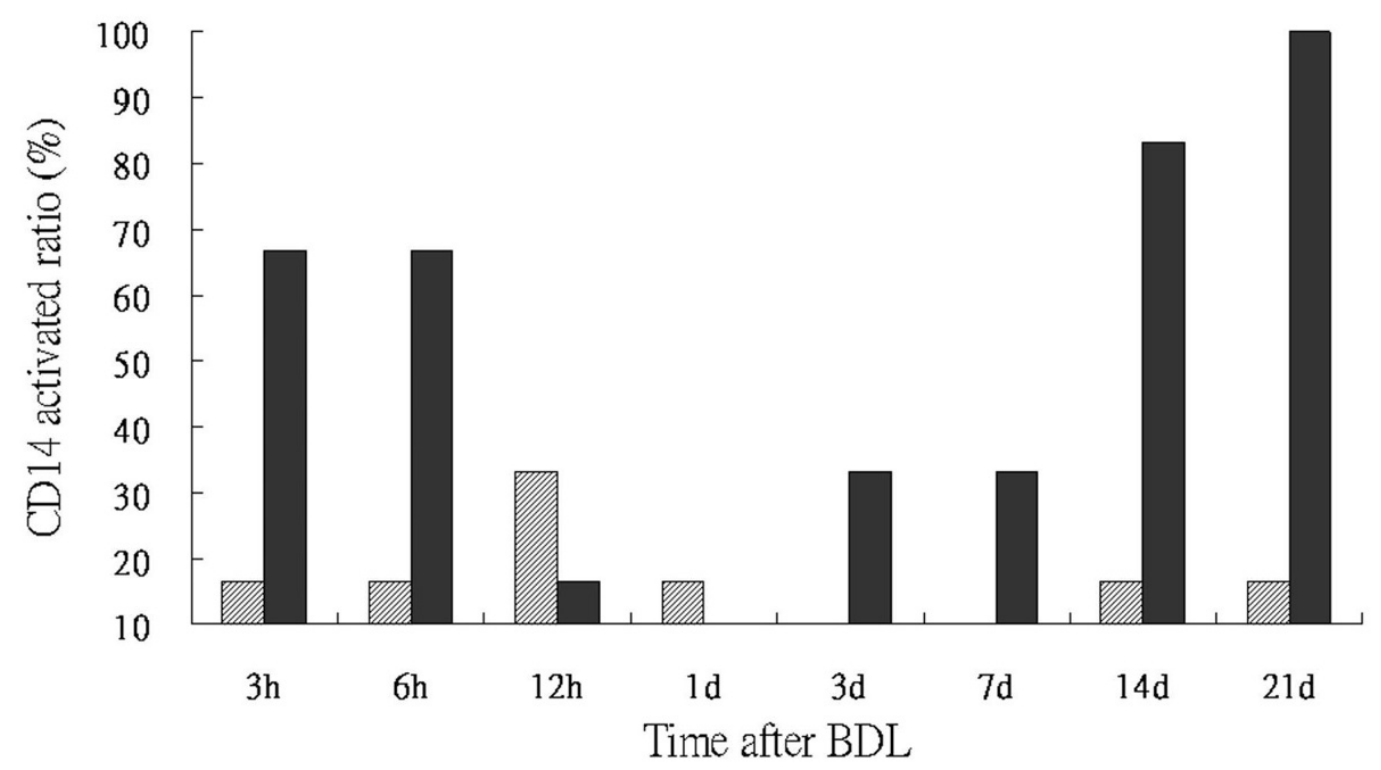

Figure 8 CD14 expression in the liver tissues of rats. CD14 staining in the liver tissues of rats from the sham and BDL groups. Staining of liver sections using a polyclonal antibody against CD14 shows negligible or no staining in any liver cells in the control (A). Positive staining in the Kupffer cells (arrow), the sinusoidal endothelial cells (arrowhead) and more strongly in hepatocytes around the portal zones at $3 \mathrm{~h}$ after sham-operation (B), and at $3 \mathrm{~h}, 1 \mathrm{~d}, 1 \mathrm{w}, 3 \mathrm{w}(\mathrm{C}-\mathrm{F})$ after BDL. Tissues were counterstained with hematoxylin. Original magnification: $\times 200$. The ratio of CD14 activated (CD14 positive cells were present in over 10\% of the tissue area) of the sham (pale bar) and BDL (black bar) groups (G). 
Table 2 Indexes e of rat liver tissues with positive reaction

\begin{tabular}{lcccc}
\hline & \multicolumn{4}{c}{ Indexes } \\
\cline { 2 - 5 } & \multicolumn{2}{c}{ CD14 activation } & \multicolumn{2}{c}{ Endotoxin } \\
\hline Time & Sham & Ligation & Sham & Ligation \\
\hline & $N(\%)^{*}$ & $N(\%)$ & $N(\%)$ & $N(\%)$ \\
$3 h(n=6)$ & $1(16.7)$ & $4(66.7)$ & $6(100)$ & $6(100)$ \\
$6 h(n=6)$ & $1(16.7)$ & $4(66.7)$ & 0 & $4(66.7)$ \\
$12 h(n=6)$ & $2(33.3)$ & $1(16.7)$ & $1(16.7)$ & $3(50)$ \\
$24 h(n=6)$ & $1(16.7)$ & 0 & 0 & $1(16.7)$ \\
$3 d(n=6)$ & 0 & $2(33.3)$ & $1(16.7)$ & $1(16.7)$ \\
$7 d(n=6)$ & 0 & $2(33.3)$ & 0 & $5(83.3)$ \\
$14 d(n=6)$ & $1(16.7)$ & $5(83.3)$ & $1(16.7)$ & $6(100)$ \\
$21 d(n=6)$ & $1(16.7)$ & $6(100)$ & 0 & $6(100)$ \\
\hline
\end{tabular}

*Immunohistochemical CD14 and endotoxin staining in the liver tissues of rat among

sham and common bile duct ligation group. The positive cells were $>10 \%$ as positive. out its function of clearing endotoxin from the blood stream [26,27].

CD14 expression in the liver increased in many types of liver disease, including alcohol and cholestatic liver injuries in rodents [17,28-30]. Immunohistochemical analysis performed in this study showed higher CD14 expression in Kupffer cells and sinusoidal endothelial cells in early-stage BA relative to late-stage BA. When the phagocytic function of Kupffer cells is impaired in cholestasis, portal derived endotoxin may accumulate in the liver and spill over into the peripheral circulation from the intestine [31-33] It is suspected that high expression of CD14 in Kupffer cells and sinusoidal endothelial cells may imply a response of these cells to cholestatic liver injury or to increased endotoxin as a result of cholestasis. However, the localization of CD14 mRNA was mainly observed in hepatocytes and bile
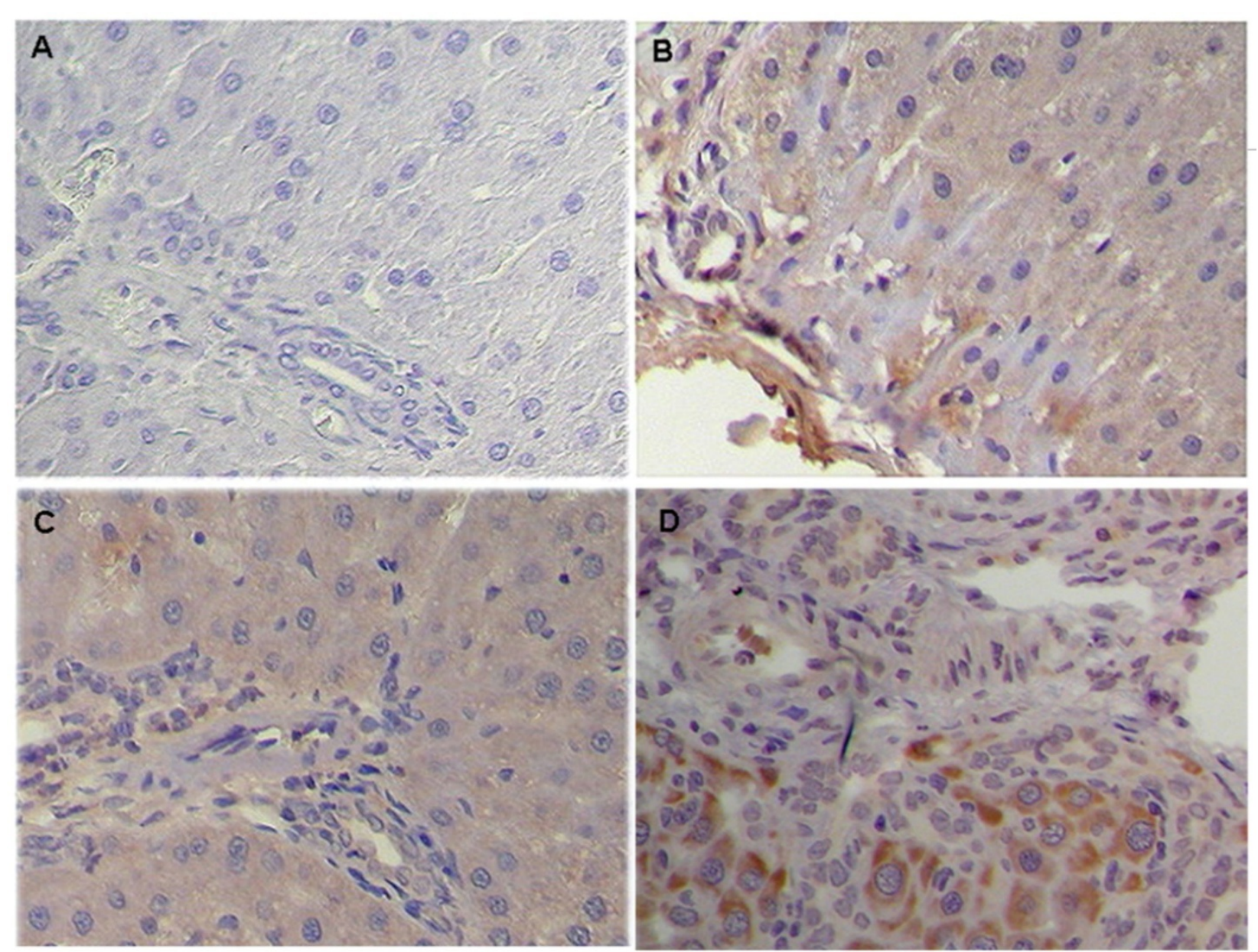

Figure 9 CD14 mRNA expression in the liver tissues of rats. In situ hybridization of CD14 mRNA in the livers from sham operated and BDL groups. CD14 is stained brown by in situ hybridization with a DIG-labeled CD14 antisense RNA probe. The paraffin-embedded sections were hybridized with a sense RNA probe against CD14 in normal tissues as a negative control (A). CD14 is expressed throughout the parenchyma of the liver tissues of normal controls (B), sham-operated (C) and BDL (D) for 14 days. Tissues were counterstained with hematoxylin. Original magnification: $\times 200$. 


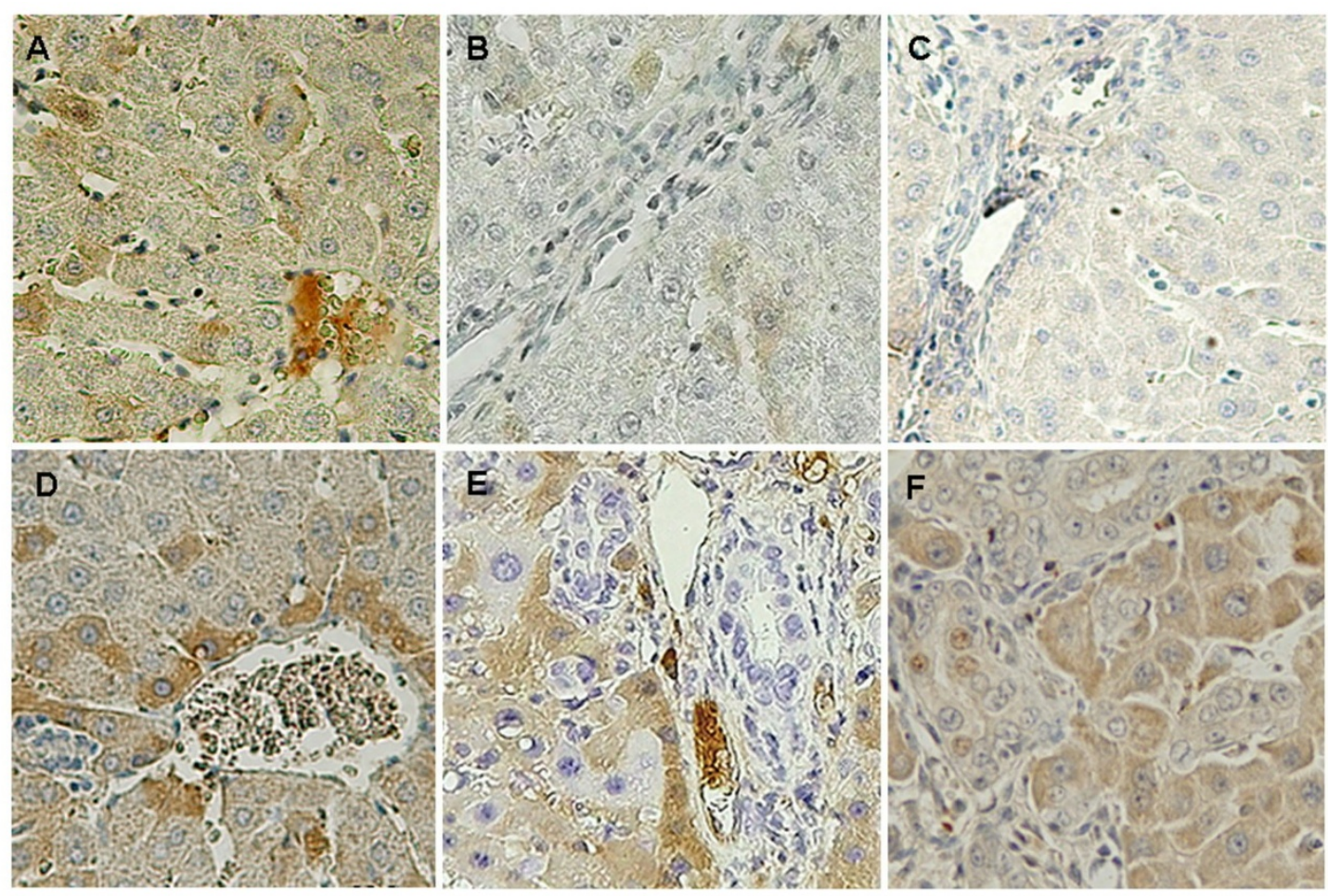

\section{G}

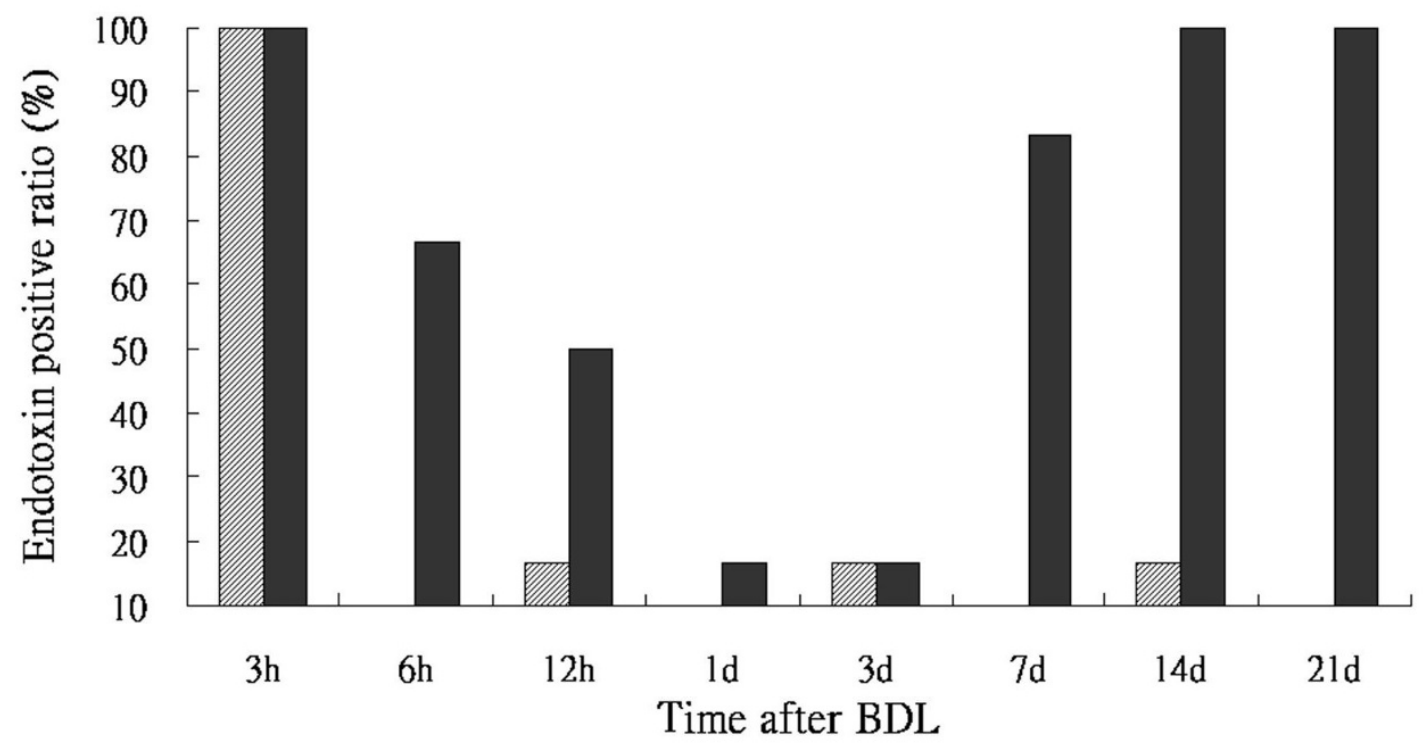

Figure 10 Endotoxin staining in the liver tissues of rats. Immunohistochemical stain of the liver sections using a monoclonal antibody against lipid A shows positive staining in the Kupffer cells, hepatocytes, and the sinusoidal endothelial cells at $3 \mathrm{~h}$ (A), 1 week r(B) and 3 week (C) after sham-operated; and at $3 \mathrm{~h}(\mathrm{D}), 1$ week (E) and 3 week (F) after BDL. Tissues were counterstained with hematoxylin. Original magnification: $\times 200$. Statistical analyses of the immunohistochemical score of $>10 \%$ endotoxin in liver sections of the sham (pale bar) and BDL groups (black bar) (G). 
duct epithelial cells. Therefore, we cannot rule out the possibility that CD14 production by hepatocytes and bile duct epithelial cells during cholestasis and its subsequent transportation to the Kupffer cells and sinusoidal endothelial cells produces an unknown downstream effect. Our results provided evidence that BA does not exempt from endotoxin accumulation in the peripheral circulation and liver, just like other cholestatic disorders. sCD14 have been demonstrated direct secretion by hepatocytes during early-stage of BA to enhance endotoxin clearance $[15,34]$. During cholestasis, the accumulation of endotoxin may induce hepatocyte injury and impair CD14 synthesis during late-stage BA.

Although studies of liver injury should take into account the relative contributions of CD14 in Kupffer cells and hepatocytes, few reports document the proportional change of $\mathrm{mCD} 14$ and $\mathrm{sCD} 14$ in the liver and the consequent pathogenetic effects on cholestatic diseases $[16,29]$. The balance between activation and inhibition of endotoxin responses by sCD14 depends on its concentration $[35,36]$. At a higher physiological concentration, sCD14 can compete with mCD14 and inhibit LPS activation of CD14-positive cells [35,36]. It is likely that increased plasma levels of sCD14 during early-stage BA observed in this study implies a protective mechanism in the liver that guards against increased endotoxin due to cholestasis. Conversely, decreased sCD14 in late-stage $\mathrm{BA}$, without a concomitant decrease of endotoxin in the liver and blood, may indicate a loss of protection against CD14-mediated LPS activation in Kupffer cells that propagates inflammatory reactions and fibrogenesis, resulting in irreversible liver injury and end-stage liver cirrhosis in patients with BA [10,16,35].

In an animal model system injected intraperitoneally with LPS, the initial and rapid induction of CD14 expression in myeloid cells is followed by a second, slower response in epithelial cells, which peaks at 8-16 h [37]. This epithelial cell response appears to require higher concentrations of LPS induction and is dependent on TNF- $\alpha$ to promote synthesis of CD14 [38]. Apart from its apparent role as an LPS receptor that mediates activation of myeloid cells, CD14 also appears to serve as an opsonic receptor for engulfment by phagocytes, resulting in clearance of LPS. Liver is the main clearance organ for intravenously injected LPS, and this is mediated by Kupffer cells, sinusoidal cells, granulocytes, and hepatocytes in rats [39]. There is evidence to suggest that LPS may be cleared from the liver via the bile canalicular system into the gut. Indeed, $3 \mathrm{~h}$ after LPS injection, bile samples taken from the gall bladder of rabbits contained substantial amounts of LPS, equivalent to that found in the plasma [40]. In our BDL rat model, we confirmed that endotoxemia and hepatocyte CD14 production occurred after ligation. CD14 was expressed in an LPS-inducible manner in Kupffer cells, neutrophils, hepatocytes, and bile duct epithelium, suggesting a possible role for CD14 in hepatocytes during the uptake and clearance of LPS from the circulation. However the endotoxin levels in liver tissues were still high due to cholestasis, and CD14 production was increased again at 7 days after ligation.

Although sCD14 has been observed in normal human serum and is increased in sera from septic patients $[14,41]$. The origin of sCD14 has yet to be determined. It has been assumed that $\mathrm{SCD} 14$ is derived from the membrane bound form present on myeloid cells either by phospholipase cleavage of the GPI anchor or by protease digestion [14]. However, patients with paroxysmal nocturnal hemoglobinuria have normal sCD14 levels in their sera, although monocytes from these patients do not express CD14 on their surface [42]. Our observation that the CD14 mRNA is detected in hepatocytes raises the possibility that sCD14 may also originate from these cells. Recent studies have shown that the CD14 antigen is expressed in many types of cells and tissues $[37,43,44]$. Some reports suggest that $\mathrm{sCD} 14$ behaves like other acute-phase proteins [14]. Hepatocytes are the major source of most acute-phase proteins; therefore, hepatocytes might be expected to express CD14, which is upregulated during endotoxemia induced by cholestasis $[10,16,39]$. These results are in agreement with other previous reports that demonstrated the synthesis and expression of CD14 are markedly upregulated by LPS during endotoxemia induced by cholestasis $[3,8,43]$. In the liver, besides hepatocytes, nonparenchymal cells such as Kupffer cells, endothelial cells, neutrophils, and other cells can also express the CD14 mRNA and synthesize the CD14 protein $[21,22,26]$, but the fact that both isolated hepatocytes and hepatic tissues express the CD14 protein and its mRNA indicate that the nonparenchymal cells could hardly have any effect on such expression in liver tissues. Although we do not provide direct evidence here that sCD14 in the plasma originates from hepatocytes during endotoxemia, our results showed that there was the possibility that the liver is an important source of sCD14 during endotoxemia. Pan et al [21]. found that the liver is one of the major organs involved in the production of sCD14. Liu et al [26] also reported that CD14 transcription rates are significantly increased in hepatocytes from LPS-treated rats, indicating that the upregulation of CD14 mRNA levels observed in rat hepatocytes after LPS treatment is dependent, in part, on increased transcription. Their observations also support the idea that sCD14 could be an acute-phase protein and hepatocytes might be a source of circulating $\mathrm{SCD} 14$ production. Our data indicated that hepatocytes from BDL rats expressed higher amounts of CD14 mRNA and protein and may have released more $\mathrm{sCD} 14$ for promoting endotoxin clearance. 


\section{Conclusions}

In conclusion, our in vivo data indicated the liver as a main source of sCD14 production during endotoxemia. However, the significantly decreased $\mathrm{sCD} 14$ expression in late-stage BA without a concomitant decrease in plasma endotoxin levels suggested that the pathogenetic mechanism underlying CD14-mediated liver injury during BA is still unresolved.

\section{Abbreviations}

$(B A)$ : biliary atresia; (BDL): bile duct ligation; (KP): Kasai procedure; (qRT-PCR): real-time quantitative reverse-transcription polymerase chain reaction

\section{Acknowledgements}

We thank Drs. Chih-Sung Hsieh and Shin-Ye Lee and the liver transplant team for providing the samples used in this study. This study was supported by grant \#NSC 92-2314-B-182-076 and \# NSC 92-2314-B-182-076 from the National Science Council, Taiwan.

\section{Author details}

'Institute of Basic Medical Sciences, National Chang Kung University, Tainan, Taiwan. ${ }^{2}$ Graduate Institute of Clinical Medical Sciences, Chang Gung University, Kaohsiung, Taiwan. ${ }^{3}$ Department of Surgery, Chang Gung Memorial Hospital - Kaohsiung Medical Center, Chang Gung University College of Medicine, Kaohsiung, Taiwan. ${ }^{4}$ Department of Pathology, Chang Gung Memorial Hospital - Kaohsiung Medical Center, Chang Gung University College of Medicine, Kaohsiung, Taiwan. ${ }^{5}$ Department of Laboratory Medicine, E-DA Hospital/I-SHOU University, Kaohsiung, Taiwan. ${ }^{6}$ Department of Medical Research, E-DA Hospital/I-SHOU University, Kaohsiung, Taiwan.

\section{Authors' contributions}

MHC performed the experiments and drafted the manuscript. JHC designed the experiment and clinical specimen collection. HLE was the pathologist and evaluated the histopathology of the cases. CMC participated in experiment performance and technical support. CHW helped analyze the data. CLC coordinated the study and drafted the manuscript. TML provided scientific advice, discussions of data and submitted the manuscript. All authors read and approved the final manuscript.

\section{Competing interests}

The authors declare that they have no competing interests.

Received: 13 October 2010 Accepted: 21 December 2010 Published: 21 December 2010

\section{References}

1. Bassett MD, Murray KF: Biliary atresia: recent progress. J Clin Gastroenterol 2008, 42:720-729.

2. Hartley $\mathrm{JL}$, Davenport M, Kelly DA: Biliary atresia. Lancet 2009, 374:1704-1713

3. Wadhwani SI, Turmelle YP, Nagy R, Lowell J, Dillon P, Shepherd RW: Prolonged neonatal jaundice and the diagnosis of biliary atresia: a single-center analysis of trends in age at diagnosis and outcomes. Pediatrics 2008, 121:e1438-1440.

4. Reyes H, Zapata R, Hernandez I, Gotteland M, Sandoval L, Jiron MI, Palma J, Almuna R, Silva JJ: Is a leaky gut involved in the pathogenesis of intrahepatic cholestasis of pregnancy? Hepatology 2006, 43:715-722.

5. Marpegan L, Leone MJ, Katz ME, Sobrero PM, Bekinstein TA, Golombek DA: Diurnal variation in endotoxin-induced mortality in mice: correlation with proinflammatory factors. Chronobiol Int 2009, 26:1430-1442.

6. Andonegui $\mathrm{G}$, Zhou H, Bullard D, Kelly MM, Mullaly SC, McDonald B, Long EM, Robbins SM, Kubes P: Mice that exclusively express TLR4 on endothelial cells can efficiently clear a lethal systemic Gram-negative bacterial infection. J Clin Invest 2009, 119:1921-1930.

7. Neyrinck AM, Taper HS, Gevers V, Declerck B, Delzenne NM: Inhibition of Kupffer cell activity induces hepatic triglyceride synthesis in fasted rats, independent of lipopolysaccharide challenge. J Hepatol 2002, 36:466-473.
8. Klintman D, Li X, Santen S, Schramm R, Jeppsson B, Thorlacius H: p38 mitogen-activated protein kinase-dependent chemokine production, leukocyte recruitment, and hepatocellular apoptosis in endotoxemic liver injury. Ann Surg 2005, 242:830-838, discussion 838-839.

9. Ramnath RD, Ng SW, Guglielmotti A, Bhatia M: Role of MCP-1 in endotoxemia and sepsis. Int Immunopharmacol 2008, 8:810-818.

10. Leicester KL, Olynyk JK, Brunt EM, Britton RS, Bacon BR: Differential findings for CD14-positive hepatic monocytes/macrophages in primary biliary cirrhosis, chronic hepatitis C and nonalcoholic steatohepatitis. Liver Int 2006, 26:559-565.

11. Lin YF, Lee HM, Leu SJ, Tsai YH: The essentiality of PKCalpha and PKCbetal translocation for CD14+monocyte differentiation towards macrophages and dendritic cells, respectively. J Cell Biochem 2007, 102:429-441.

12. Nicu EA, van der Velden U, Everts V, Loos BG: Expression of FcgammaRs and mCD14 on polymorphonuclear neutrophils and monocytes may determine periodontal infection. Clin Exp Immunol 2008, 154:177-186.

13. Zhao Z, Fleming R, McCloud B, Klempner MS: CD14 mediates cross talk between mononuclear cells and fibroblasts for upregulation of matrix metalloproteinase 9 by Borrelia burgdorferi. Infect Immun 2007 , 75:3062-3069.

14. Bas S, Gauthier BR, Spenato U, Stingelin S, Gabay C: CD14 is an acutephase protein. J Immunol 2004, 172:4470-4479.

15. Ahmed AF, Nio M, Ohtani H, Nagura H, Ohi R: In situ CD14 expression in biliary atresia: comparison between early and late stages. J Pediatr Surg 2001, 36:240-243.

16. Shih $\mathrm{HH}$, Lin $\mathrm{TM}$, Chuang $\mathrm{JH}$, Eng HL, Juo SH, Huang $\mathrm{FC}$, Chen $\mathrm{CL}$, Chen $\mathrm{HL}$ : Promoter polymorphism of the CD14 endotoxin receptor gene is associated with biliary atresia and idiopathic neonatal cholestasis. Pediatrics 2005, 116:437-441.

17. Isayama F, Hines IN, Kremer M, Milton RJ, Byrd CL, Perry AW, McKim SE, Parsons C, Rippe RA, Wheeler MD: LPS signaling enhances hepatic fibrogenesis caused by experimental cholestasis in mice. Am J Physiol Gastrointest Liver Physiol 2006, 290:G1318-1328.

18. Von Hahn T, Halangk J, Witt H, Neumann K, Muller T, Puhl G, Neuhaus P, Nickel R, Beuers U, Wiedenmann B, Berg T: Relevance of endotoxin receptor CD14 and TLR4 gene variants in chronic liver disease. Scand J Gastroenterol 2008, 43:584-592.

19. Su GL: Lipopolysaccharides in liver injury: molecular mechanisms of Kupffer cell activation. Am J Physiol Gastrointest Liver Physiol 2002, 283:G256-265.

20. Su GL, Goyert SM, Fan MH, Aminlari A, Gong KQ, Klein RD, Myc A, Alarcon WH, Steinstraesser L, Remick DG, Wang SC: Activation of human and mouse Kupffer cells by lipopolysaccharide is mediated by CD14. Am J Physiol Gastrointest Liver Physiol 2002, 283:G640-645.

21. Pan Z, Zhou L, Hetherington CJ, Zhang DE: Hepatocytes contribute to soluble CD14 production, and CD14 expression is differentially regulated in hepatocytes and monocytes. J Biol Chem 2000, 275:36430-36435.

22. Su GL, Dorko K, Strom SC, Nussler AK, Wang SC: CD14 expression and production by human hepatocytes. J Hepatol 1999, 31:435-442.

23. Wilkinson DG: RNA detection using non-radioactive in situ hybridization. Curr Opin Biotechnol 1995, 6:20-23.

24. Gegner JA, Ulevitch RJ, Tobias PS: Lipopolysaccharide (LPS) signal transduction and clearance. Dual roles for LPS binding protein and membrane CD14. J Biol Chem 1995, 270:5320-5325.

25. Kitchens RL, Munford RS: CD14-dependent internalization of bacterial lipopolysaccharide (LPS) is strongly influenced by LPS aggregation but not by cellular responses to LPS. J Immunol 1998, 160:1920-1928.

26. Liu S, Khemlani LS, Shapiro RA, Johnson ML, Liu K, Geller DA, Watkins SC, Goyert SM, Billiar TR: Expression of CD14 by hepatocytes: upregulation by cytokines during endotoxemia. Infect Immun 1998, 66:5089-5098.

27. Mimura Y, Sakisaka S, Harada M, Sata M, Tanikawa K: Role of hepatocytes in direct clearance of lipopolysaccharide in rats. Gastroenterology 1995, 109:1969-1976.

28. Su GL, Rahemtulla A, Thomas P, Klein RD, Wang SC, Nanji AA: CD14 and lipopolysaccharide binding protein expression in a rat model of alcoholic liver disease. Am J Pathol 1998, 152:841-849.

29. Tracy TF Jr, Fox ES: CD14-lipopolysaccharide receptor activity in hepatic macrophages after cholestatic liver injury. Surgery 1995, 118:371-377.

30. Zuo GQ, Gong JP, Liu CA, Li SW, Wu XC, Yang K, Li Y: Expression of lipopolysaccharide binding protein and its receptor CD14 in experimental alcoholic liver disease. World J Gastroenterol 2001, 7:836-840. 
31. Kaser A, Ludwiczek O, Waldenberger P, Jaschke W, Vogel W, Tilg H: Endotoxin and its binding proteins in chronic liver disease: the effect of transjugular intrahepatic portosystemic shunting. Liver 2002, 22:380-387.

32. Roughneen PT, Drath DB, Kulkarni AD, Rowlands BJ: Impaired nonspecific cellular immunity in experimental cholestasis. Ann Surg 1987, 206:578-582.

33. Sasatomi K, Noguchi K, Sakisaka S, Sata M, Tanikawa K: Abnormal accumulation of endotoxin in biliary epithelial cells in primary biliary cirrhosis and primary sclerosing cholangitis. J Hepatol 1998, 29:409-416.

34. Lee JW, Paape MJ, Elsasser TH, Zhao X: Recombinant soluble CD14 reduces severity of intramammary infection by Escherichia coli. Infect Immun 2003, 71:4034-4039.

35. Chuang JH, Chou MH, Wu CL, Du YY: Implication of innate immunity in the pathogenesis of biliary atresia. Chang Gung Med J 2006, 29:240-250.

36. Kitchens RL, Thompson PA: Modulatory effects of SCD14 and LBP on LPShost cell interactions. J Endotoxin Res 2005, 11:225-229.

37. Fearns C, Kravchenko W, Ulevitch RJ, Loskutoff DJ: Murine CD14 gene expression in vivo: extramyeloid synthesis and regulation by lipopolysaccharide. J Exp Med 1995, 181:857-866.

38. Fearns C, Loskutoff $D J$ : Role of tumor necrosis factor alpha in induction of murine CD14 gene expression by lipopolysaccharide. Infect Immun 1997, 65:4822-4831.

39. Li SW, Gong JP, Wu CX, Shi YJ, Liu CA: Lipopolysaccharide induced synthesis of CD14 proteins and its gene expression in hepatocytes during endotoxemia. World J Gastroenterol 2002, 8:124-127.

40. Schimke J, Mathison J, Morgiewicz J, Ulevitch RJ: Anti-CD14 mAb treatment provides therapeutic benefit after in vivo exposure to endotoxin. Proc Natl Acad Sci USA 1998, 95:13875-13880.

41. Landmann R, Reber AM, Sansano S, Zimmerli W: Function of soluble CD14 in serum from patients with septic shock. J Infect Dis 1996, 173:661-668.

42. Schutt C, Schilling T, Grunwald U, Stelter F, Witt S, Kruger C, Jack RS: Human monocytes lacking the membrane-bound form of the bacterial lipopolysaccharide (LPS) receptor CD14 can mount an LPS-induced oxidative burst response mediated by a soluble form of CD14. Res Immunol 1995, 146:339-350.

43. Kimmings AN, van Deventer SJ, Obertop H, Rauws EA, Huibregtse $K$ Gouma DJ: Endotoxin, cytokines, and endotoxin binding proteins in obstructive jaundice and after preoperative biliary drainage. Gut 2000, 46:725-731.

44. Nishimura M, Naito S: Tissue-specific mRNA expression profiles of human toll-like receptors and related genes. Biol Pharm Bull 2005, 28:886-892.

\section{doi:10.1186/1479-5876-8-138}

Cite this article as: Chou et al.: Endotoxin and CD14 in the progression of biliary atresia. Journal of Translational Medicine 2010 8:138.

\section{Submit your next manuscript to BioMed Central and take full advantage of:}

- Convenient online submission

- Thorough peer review

- No space constraints or color figure charges

- Immediate publication on acceptance

- Inclusion in PubMed, CAS, Scopus and Google Scholar

- Research which is freely available for redistribution

Submit your manuscript at www.biomedcentral.com/submit
Biomed Central 